\title{
PSD-93 Knock-Out Mice Reveal That Neuronal MAGUKs Are Not Required for Development or Function of Parallel Fiber Synapses in Cerebellum
}

\author{
Aaron W. McGee, ${ }^{1}$ J. Rick Topinka, ${ }^{1}$ Kouichi Hashimoto, ${ }^{2,3}$ Ronald S. Petralia, ${ }^{4}$ Sho Kakizawa, ${ }^{2,3}$ \\ Frederick Kauer, ${ }^{1}$ Andrea Aguilera-Moreno, ${ }^{1}$ Robert J. Wenthold, ${ }^{4}$ Masanobu Kano, ${ }^{2}$ and David S. Bredt ${ }^{1}$ \\ ${ }^{1}$ Department of Physiology and Programs in Biomedical Sciences and Neuroscience, University of California at San \\ Francisco School of Medicine, San Francisco, California 94143-0444, 2Department of Physiology, Kanazawa University \\ School of Medicine, Takara-machi, Kanazawa 920-8640, Japan, ${ }^{3}$ Core Research for Evolutional Science and Technology, \\ Japan Science and Technology Corporation, Kawaguchi, Saitamam 332-0012, Japan, and 4 Laboratory of \\ Neurochemistry, National Institute of Deafness and Communication Disorders, National Institutes of Health, Bethesda, \\ Maryland 20892
}

\begin{abstract}
Membrane-associated guanylate kinases (MAGUKs) are abundant postsynaptic density (PSD)-95/discs large/zona occludens-1 (PDZ)-containing proteins that can assemble receptors and associated signaling enzymes at sites of cell-cell contact, including synapses. PSD-93, a postsynaptic neuronal MAGUK, has three PDZ domains that can bind to specific ion channels, including NMDA $\delta 2$ type glutamate receptors, as well as Shaker and inward rectifier type $\mathrm{K}^{+}$channels, and can mediate clustering of these channels in heterologous cells. Genetic analyses of Drosophila show that MAGUKs play critical roles in synaptic development because mutations of discs large disrupt the subsynaptic reticulum and block postsynaptic clustering of Shaker $\mathrm{K}^{+}$channels. It is uncertain whether MAGUKs play an essential role in the development of central synapses. There are four neuronal MAGUKs with overlapping expression patterns in the mammalian brain; however,
\end{abstract}

we find PSD-93 is the only MAGUK expressed in cerebellar Purkinje neurons. Therefore, we targeted disruption of PSD-93 in mouse. Despite the absence of MAGUK immunoreactivity in Purkinje neurons from the knock-outs, these mice have no structural or functional abnormality in cerebellum. Both the dendritic architecture and the postsynaptic localization of PSD-93 interacting proteins remain intact at light and electron microscopic levels in the knock-outs. Postsynaptic Purkinje cell responses, monosynaptic climbing fiber innervation, and cerebellar-dependent behaviors are also normal. Our data demonstrate that MAGUK proteins of the PSD-93/95 family are not essential for development of certain central synapses but may instead participate in specialized aspects of synaptic signaling and plasticity.

Key words: PSD-93; Purkinje neuron; MAGUK; cerebellum; synapse; development; knock-out
Neurotransmitter receptors and signaling molecules cluster at the postsynaptic density (PSD) and are thereby poised to respond to synaptic stimuli (Walters and Matus, 1975; Carlin et al., 1981; Kennedy et al., 1983; Sheng, 1996; Kornau et al., 1997; Craven and Bredt, 1998). Recent studies suggest that a family of membrane-associated guanylate kinases (MAGUKs) play a major role in the localization of channels, signaling enzymes, and adhesion molecules to synapses (Sheng, 1996; Kim, 1997; Kornau et al., 1997; Craven and Bredt, 1998). Neuronal MAGUK proteins include PSD-95/synapse-associated protein-90 (SAP-90) and the closely related PSD-93/chapsyn-110, SAP-97/hdlg, and SAP-102, all of which are found at synapses in brain (Cho et al., 1992; Kistner et al., 1993; Muller et al., 1995, 1996; Brenman et al., 1996b; Kim et al., 1996). MAGUKs comprise one or three

\footnotetext{
Received May 23, 2000; revised Feb. 7, 2001; accepted Feb. 8, 2001.

This work was supported by grants (D.S.B) from the National Institutes of Health (R01-NS36017 and NS34822), the National Science Foundation, the National Association for Research on Schizophrenia and Depression, and the Culpeper and Beckman Foundations. A.W.M. is a Howard Hughes Predoctoral Fellow, and D.S.B. is an Established Investigator for the American Heart Association. We thank Dr. Morgan Sheng (Harvard Medical School) for the antibody to GKAP.

A.W.M. and J.R.T. contributed equally to this work.

Correspondence should be addressed to David S. Bredt, University of California at San Francisco School of Medicine, 513 Parnassus Avenue, San Francisco, CA 94143-0444. E-mail: bredt@itsa.ucsf.edu.

Copyright (C) 2001 Society for Neuroscience 0270-6474/01/213085-07\$15.00/0
}

N-terminal PSD-95/discs large/zona occludens-1 (PDZ) motifs, an $\mathrm{SH} 3$ domain, and a $\mathrm{C}$-terminal region homologous to guanylate kinases. PDZ domains mediate protein-protein interactions and bind to short amino acid motifs at the $\mathrm{C}$ termini of interacting proteins (Sheng, 1996) or to internal $\beta$-finger motifs (Hillier et al., 1999).

Several lines of biochemical experimentation suggest roles for MAGUKs in regulating assembly of synaptic protein networks at excitatory synapses. First, MAGUK proteins are major components of the postsynaptic density (Cho et al., 1992). Second, MAGUK proteins PSD-95 and PSD-93 can mediate ion channel clustering in cotransfected heterologous cells (Kim et al., 1995). Third, both NMDA receptors and neuronal nitric oxide synthase (nNOS) bind to PDZ domains from PSD-95, and downregulation of PSD-95 expression in cultured neurons selectively blocks NMDA receptor stimulation of nNOS activity (Brenman et al., 1996a; Sattler et al., 1999). Fourth, disrupting the interaction of MAGUKs with the microtubule-associated protein CRIPT interferes with synaptic localization of the guanylate kinase interacting protein GKAP (guanylate kinase domain-associated protein) (Passafaro et al., 1999). Finally, overexpression of PSD-95 in hippocampal neurons accelerates maturation of excitatory synapses (El-Husseini et al., 2000).

In addition to these biochemical data, some genetic evidence 
supports roles for MAGUKs in synaptic assembly. Mutation of the Drosophila MAGUK protein Discs Large (DLG) disrupts the synaptic clustering of the Shaker potassium channel and attenuates development of the subsynaptic reticulum at larval neuromuscular junctions (Lahey et al., 1994; Tejedor et al., 1997). Also, targeted disruption of PSD-95 in mouse dramatically alters NMDA receptor-dependent synaptic plasticity and impairs spatial learning (Migaud et al., 1998). However, this disruption of PSD-95 does not yield detectable changes in synaptic structure and does not alter synaptic localization of PSD-95 interacting proteins, such as the NMDA receptor (Migaud et al., 1998).

Functional redundancy may explain the lack of structural abnormalities in PSD-95 mutant mice. There are four neuronal MAGUKs that have overlapping distributions in brain. To help to avoid issues associated with this redundancy, we targeted disruption of PSD-93, because we find it is the only MAGUK protein expressed in cerebellar Purkinje neurons. Nevertheless, we now demonstrate that Purkinje cell synaptic structure and cerebellar functions are not detectably altered in the PSD-93 knock-outs. Thus, MAGUKs are not required for postsynaptic development of certain synapses and are not required for synaptic localization of some interacting proteins.

\section{MATERIALS AND METHODS}

Antibodies. The following primary antibodies were used: rabbit polyclonals to PSD-95 (Brenman et al., 1996b), PSD-93 (Brenman et al., 1996b), GKAP (Kim et al., 1997), and $\delta 2$ glutamate receptor (Mayat et al., 1995); guinea pig polyclonals to PSD-93 (Brenman et al., 1996b), SAP-97 (Topinka and Bredt, 1998), SAP-102 (Firestein et al., 1999), and cyclic GMP-dependent protein kinase type I (cGKI); and a mouse monoclonal to PSD-95 (Affinity Bioreagents, Golden, CO). Immunizing a guinea pig with a GST fusion to the first 340 amino acids of bovine cGKI generated the antibody to cGKI. All polyclonal antisera were affinity-purified except the antibody to cGKI.

Cloning of the PSD-93 gene and generation of knock-out mice. A bacterial artificial chromosome (BAC) SV129 mouse genomic library was screened with a cDNA probe encoding the second PDZ domain of PSD-93, and three BACs were obtained, each $\sim 100 \mathrm{~kb}$ in size. One of these clones was characterized in detail. Specifically, we found that most of the second PDZ domain is contained in a single $170 \mathrm{bp}$ exon that is flanked by introns of $>4 \mathrm{~kb}$ on each side. The targeting construct that we designed replaces this critical exon with neomycin and is flanked on the two sides by a total of $8.5 \mathrm{~kb}$ of genomic DNA (see Fig. 1). This construct was electroporated into ES cells that were cultured on neomycinresistant STO fibroblasts that had been mitotically inactivated by treatment with mitomycin. After electroporation and double drug selection with G418 and FIAU, individual cell colonies were picked, expanded, and analyzed by Southern blotting for proper homologous recombination. A total of $\sim 300$ clones were analyzed, and four were properly targeted. ES cell clones with targeted integrations were injected into mouse blastocysts, and the injected embryos were implanted into surrogate mothers. Highly chimeric mice were identified by their coat color and were mated to $\mathrm{C} 57 / \mathrm{Bl} 6$ mice. The resulting offspring were genotyped to identify germ line transmission. Mice that inherited the mutation were then interbred to produce homozygous mutant animals that lack the normal gene product. Genotyping of the mice was performed as follows by Southern blotting and the PCR: wild-type allele, primer pair 5' (GTGCGGAATGTTGTTGTGCAGTGC) and exon (CACAACAGTCTCCAGGATGGGTCG); and mutant allele, neo (CAGCGCATCGCCTTCTATCGCCTT) and primer pair 5'.

Light microscopic analysis. Adult mice were anesthetized with pentobarbital and perfused with $4 \%$ freshly depolymerized paraformaldehyde in $0.1 \mathrm{M}$ phosphate buffer. Tissues were removed and post-fixed in paraformaldehyde for $1 \mathrm{hr}$ at $4^{\circ} \mathrm{C}$. Tissues were cryoprotected overnight in $20 \%$ sucrose, and free-floating sections $(40 \mu \mathrm{m})$ were cut on a sliding microtome. Endogenous peroxidase activity was inactivated by incubating brain sections in $0.5 \% \mathrm{H}_{2} \mathrm{O}_{2}$ for $15 \mathrm{~min}$. Sections were blocked for 1 $\mathrm{hr}$ in PBS containing $1.5 \%$ normal goat serum and then incubated overnight in the same buffer containing diluted antiserum. Immunohistochemical staining used an avidin-biotin-peroxidase system (ABC
Elite; Vector Laboratories, Burlingame, CA) according to the manufacturer's instructions. Peroxidase staining was developed using 3,3'diaminobenzidine as the chromogen. Antibodies to PSD-93 and GKAP-C were both used at $1 \mu \mathrm{g} / \mathrm{ml}$, and the antibody to cGKI was diluted 1:1000 from serum in the blocking solution.

Electron microscopic analysis. Postembedding immunogold labeling was done as described previously (Petralia et al., 1997, 1998; Z hao et al., 1998; Petralia and Wenthold, 1999). Briefly, mice were perfused with 4\% paraformaldehyde plus $0.5 \%$ glutaraldehyde. After $2 \mathrm{hr}$ fixation, $300 \mu \mathrm{m}$ brain sections were prepared with a vibratome. Sections were frozen in liquid propane and embedded in Lowicryl. Thin sections were cut from blocks, treated with $0.1 \%$ sodium borohydride and $50 \mathrm{~mm}$ glycine in Tris HCl-buffered saline plus $0.1 \%$ Triton X-100 (TBST), blocked with $10 \%$ serum in TBST, incubated with primary antibody in $1 \%$ serum-TBST for $2 \mathrm{hr}$, and then washed. Sections were labeled with $10 \mathrm{~nm}$ of immunogold in $0.5 \%$ polyethylene glycol plus $1 \%$ serum-TSBT and then stained with uranyl acetate and lead citrate. Sections from two knock-out and two wild-type mice were used.

Electrophysiological analysis. Sagittal cerebellar slices of 200-250 $\mu \mathrm{m}$ thickness were prepared from the wild-type and PSD-93 mutant mice as described previously (Edwards et al., 1989; Llano et al., 1991; Kano and Konnerth, 1992; Aiba et al., 1994). A whole-cell recording was made from visually identified Purkinje cells using a $40 \times$ water immersion objective attached to either an Olympus (BX-50) or a Zeiss (Axioskop) upright microscope (Edwards et al., 1989; Llano et al., 1991). Resistance of patch pipettes was 3-6 M $\Omega$ when filled with an intracellular solution containing (in $\mathrm{nm}$ ): $60 \mathrm{CsCl}, 30 \mathrm{Cs}$ D-gluconate, 20 tetraethylammonium (TEA)-Cl, 20 BAPTA, $4 \mathrm{MgCl}_{2}, 4 \mathrm{ATP}$, and $30 \mathrm{HEPES}, \mathrm{pH} 7.3$, adjusted with $\mathrm{CsOH}$. The composition of the standard bathing solution was (in mM): $125 \mathrm{NaCl}, 2.5 \mathrm{KCl}, 2 \mathrm{CaCl}_{2}, 1 \mathrm{MgSO}_{4}, 1.25 \mathrm{NaH}_{2} \mathrm{PO}_{4}, 26$ $\mathrm{NaHCO}_{3}$, and 20 glucose; this solution was bubbled continuously with a mixture of $95 \% \mathrm{O}_{2}$ and $5 \% \mathrm{CO}_{2}$. Bicuculline $(10 \mu \mathrm{M})$ was always present in the saline to block spontaneous inhibitory postsynaptic currents (Kano et al., 1992). Ionic currents were recorded with either Axopatch-1D (Axon Instruments, Foster City, CA) or EPC-9 patch-clamp amplifier (HEKA Elektonik, Lambrecht/Pfalz, Germany). Stimulation and online data acquisition were performed using the PULSE software on a Macintosh computer (version 8.1; HEKA Elektonik). The signals were filtered at $3 \mathrm{kHz}$ and digitized at $20 \mathrm{kHz}$. Fitting of the decay phases of EPSCs was performed with the PULSE-FIT software (version 8.1; HEKA Elektonik). For stimulation of climbing fibers (CFs) and parallel fibers (PFs), we used a glass pipette with 5-10 $\mu \mathrm{m}$ tip diameter filled with standard saline. Square pulses (duration, $0.1 \mathrm{msec}$; amplitude, 0-100 V for climbing fiber stimulation, $1-10 \mathrm{~V}$ for parallel fiber stimulation) were applied for focal stimulation.

Behavioral analysis. The rotorod (model 7650; Ugo Basile, Comerio, Italy) apparatus consists of a horizontal mast rotating around its longitudinal axis. It is divided into sections that are separated by pieces of opaque plastic to isolate the individual animals. Littermates were dropped gently onto the rotating beam at the slowest speed setting, facing away from the tester, and trained for $2 \mathrm{~min}$ at the slowest speed setting. Each mouse was trained three times. After the training session, mice were placed on the apparatus again at the slowest speed setting. Once all of the mice were in position, the rotorod was switched to the accelerate mode and the mice were timed for the duration they remained on the rod. The trial was completed when either the mouse fell from the device or $250 \mathrm{sec}$ had elapsed.

\section{RESULTS}

\section{Generation of PSD-93 knock-out mice by homologous recombination}

We chose to delete coding sequences in the second PDZ domain of PSD-93, which binds to multiple MAGUK ligands (Kornau et al., 1995; Brenman et al., 1996a) and is also critical for synaptic localization of MAGUK proteins (Craven et al., 1999). The translation of the deleted exon is identical to residues 146-201 of rat PSD-93. Using the PCR, we designed a targeting vector that replaces the targeted exon with the neomycin cassette. This cassette is flanked on the $5^{\prime}$ side by a $5 \mathrm{~kb}$ intronic fragment and on the $3^{\prime}$ side by a $3.5 \mathrm{~kb}$ intronic fragment. A thymidine kinase cassette was added upstream of the $5^{\prime}$ intronic sequence to permit double selection (Fig. 1). 
A
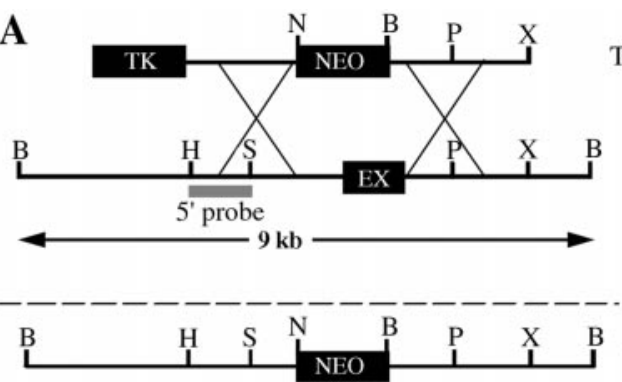

Targeting vector

B

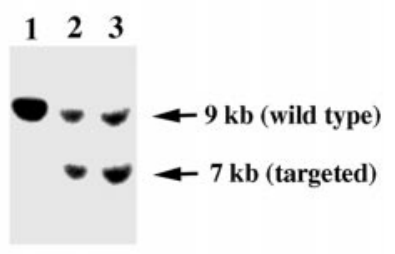

Figure 1. Targeted disruption of PSD-93. A, Restriction maps of the pTK/NEO targeting vector, the native PSD-93 gene, and the properly targeted deletion locus are shown. Recombination (shown as large $X s$ ) between the targeting vector and the wild-type locus produced the targeted allele. A Bam $\mathrm{HI}$ site was engineered into the $3^{\prime}$ end of the Neo cassette of the targeting vector to facilitate genotyping. B, Bam HI; H, HindIII; N, NheI; P, PstI; S, SacI; $X, X b a \mathrm{I}$. B, Southern blotting of BamHI digests of genomic DNA from three drug-selected ES cells demonstrates proper targeting of the PSD-93 gene. A probe to the region immediately $5^{\prime}$ of the targeting vector yields a $9 \mathrm{~kb}$ fragment for the wild-type allele and a $7 \mathrm{~kb}$ fragment for properly targeted alleles.
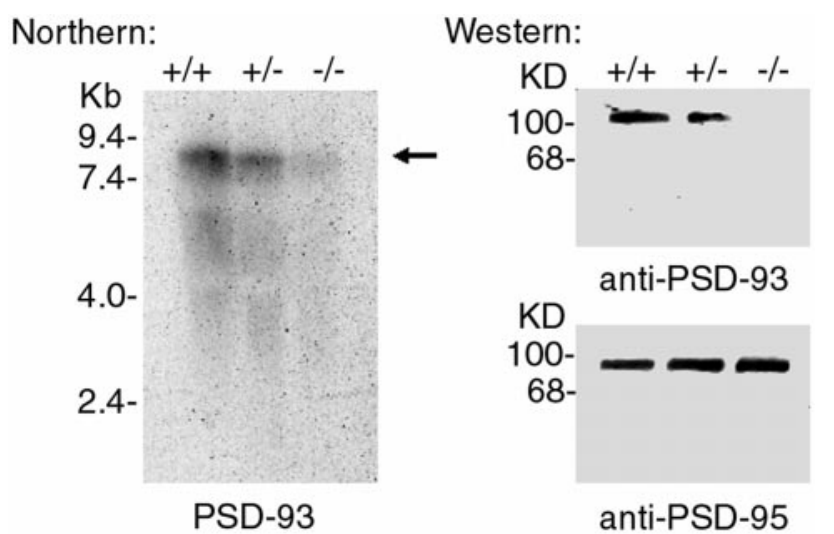

Figure 2. Analysis of mRNA and protein expression in brain of PSD-93 knock-out mice. RNA and protein from wild-type $(+/+)$, heterozygous $(+/-)$, and knock-out $(-/-)$ mice were analyzed for PSD-93 RNA expression (left) or for PSD-93 (top right) or PSD-95 (bottom right) protein expression. In the knock-out, expression of PSD-93 RNA is highly reduced, and PSD-93 protein (detected with a peptide antibody to amino acids 22-37) is undetectable. PSD-95 protein expression appears normal in the PSD-93 knock-outs.

The targeting vector was linearized with $X b a \mathrm{I}$ and electroporated into mouse embryonic stem cells, which were then selected with G418 and FIAU. Double resistant clones were analyzed by Southern blotting and PCR. Appropriately targeted clones (3 of 400) were injected into blastocytes, and the resulting chimeric mice were used to breed heterozygous and homozygous mice, which were genotyped by Southern blotting (Fig. 1). Intercrosses of heterozygous mice showed that PSD-93 knock-outs are born at the predicted Mendelian frequency; furthermore, both males and females are viable and fertile.

\section{Biochemical analysis of mutant mice lacking PSD-93}

We first used Northern blotting to assess PSD-93 mRNA expression in brains from mutant mice. In wild-type mice, PSD-93 mRNA migrates as a relatively diff use band at $\sim 7.5 \mathrm{~kb}$ (Brenman et al., 1996b). The intensity of this band is diminished by $\sim 50 \%$ in brain from heterozygous mice (Fig. 2). In the homozygous mutants, a very weak band of slightly faster mobility $(\sim 7 \mathrm{~kb})$ is detected. The nature of the residual PSD-93 mRNA remaining in the brains of the knock-out is unclear, but it likely derives from alternative splicing that skips the deleted exon. This residual

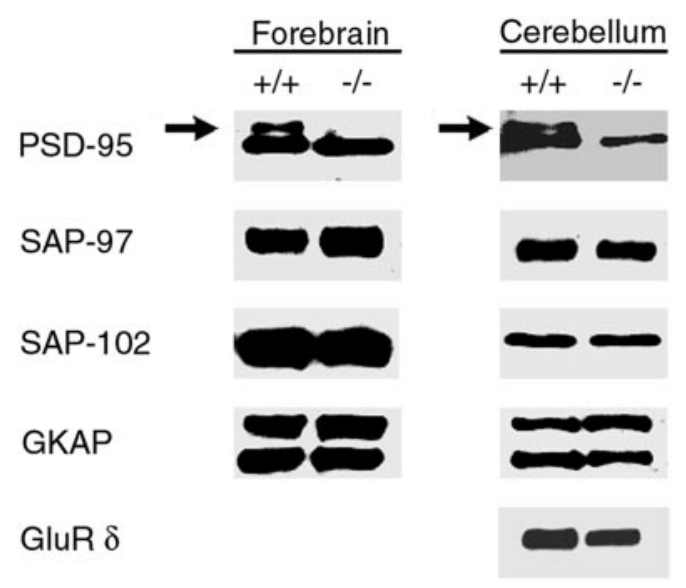

Figure 3. Expression of postsynaptic proteins in PSD-93 knock-out mice. Protein expression of PSD-95, SAP-102, and SAP-97 is not affected by the absence of PSD-93. Note that in extracts from wild-type mice, the monoclonal antibody to PSD-95 (Affinity Bioreagents) cross-reacts with a band of slightly slower migration, which corresponds to PSD-93 (arrow). Levels of GKAP and $\delta 2$ glutamate receptor were also unchanged in the PSD-93 knock-outs. Crude homogenates from forebrain and cerebellum of wildtype $(+/+)$ and knock-out $(-/-)$ mice were separated by SDS-PAGE and probed by Western blotting.

mRNA is apparently not translated into PSD-93 protein because immunoblotting of brain extracts with an antibody raised to an epitope N-terminal to the deleted exon shows that PSD-93 protein is absent in the knock-out mice (Fig. 2). As expected, PSD-93 protein levels in the heterozygous mice are $\sim 50 \%$ of those found in wild types.

The grossly normal phenotype of the PSD-93 knock-out mice suggested that other MAGUKs might have compensated for the absence of PSD-93. However, Western blotting revealed that levels of the other three neuronal MAGUKs, PSD-95, SAP-97, and SAP-102, all occur at normal levels in the brains of the knock-out mice (Fig. 3).

\section{Normal synaptic architecture in PSD-93 knock-out mice}

To determine whether loss of PSD-93 yields anatomical changes in brain, we performed immunohistochemical staining of wildtype and PSD-93 knock-out mice. Our analysis focused on the cerebellum because PSD-93 is the only MAGUK protein present 

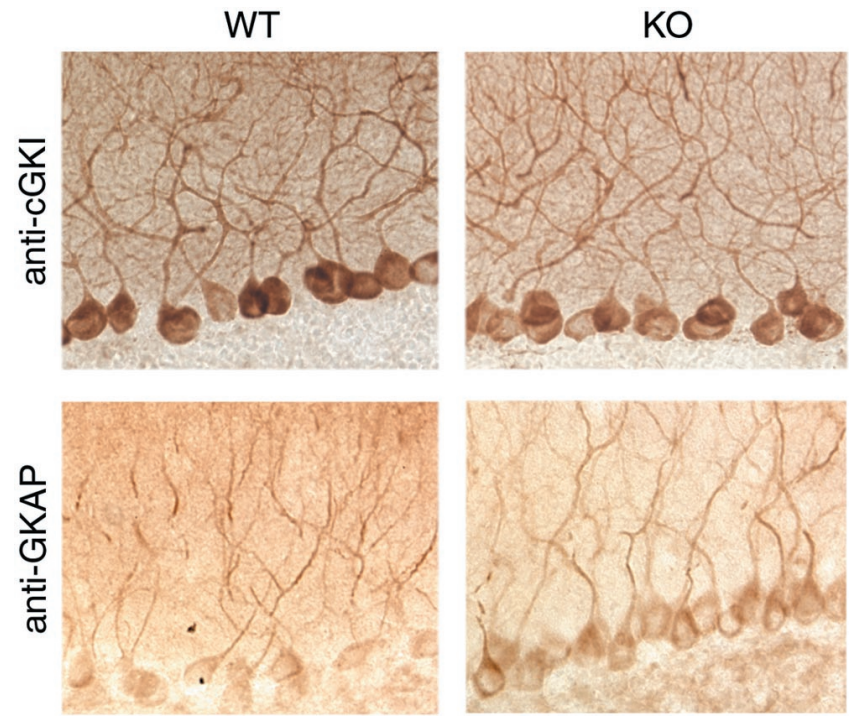

Figure 4. Cerebellar Purkinje cell architecture and GKAP expression appear normal in PSD-93 knock-out mice. The Purkinje cells of PSD-93 knock-out mice display normal dendritic arborizations and somatodendritic localizations for GMP-dependent protein kinase type I ( $c G K I)$ and GKAP. Cerebella from wild-type (WT) and PSD-93 knock-out mice $(K O)$ were stained using antibodies to cGKI and GKAP. Magnification, $40 \times$.

in cerebellar Purkinje neurons. As shown in Figure 4, we found that the overall structure of the cerebellum was intact. The granule, Purkinje, and molecular layers appeared normal, as did the dendritic arborization of the Purkinje neurons, when visualized with an antibody to cGKI. Furthermore, ultrastructural analysis of cerebellum showed that both climbing and parallel fiber synapses onto Purkinje cells have normal morphologies in the knock-out mice (Fig. 5; data not shown).

Immunohistochemical staining also was used to assess the distribution of MAGUK proteins in cerebellum of PSD-93 knock-outs. We used an antibody (raised to the PDZ domains of PSD-93) that efficiently cross-reacts with several members of the MAGUK family. In cerebellum of wild-type mice, this "panMAGUK" antibody labels glomeruli in the granule cell layer (reflecting SAP-97 and SAP-102), pinceaux beneath the Purkinje cell bodies (reflecting PSD-95), and dendritic arbors of cerebellar Purkinje neurons (reflecting PSD-93). In the knock-out mice, staining of glomeruli and pinceaux is preserved, whereas Purkinje cell staining is selectively abolished (Fig. 6). This suggests that PSD-93 is the only neuronal MAGUK normally expressed in cerebellar Purkinje cells and that other MAGUK isoforms are not induced in Purkinje neurons of the knock-out mice. Using isoform-specific antibodies, we found that the cellular distributions of PSD-95, SAP-97, and SAP-102 in cerebellum are unaltered in PSD-93 knock-out mice and are absent from Purkinje cells (Fig. 5).

\section{Lack of PSD-93 does not affect localization of PSD-93 interacting proteins}

MAGUK proteins are thought to mediate synaptic localization of interacting proteins such as ion channels and the guanylate kinase interacting protein, GKAP (Kim et al., 1997). Because PSD-93 is the only MAGUK that occurs in cerebellar Purkinje cells, we focused our analysis on this cell type. However, immunohistochemical staining revealed that the somatodendritic localization of GKAP is unchanged in the cerebellum of PSD-93 knock-outs (Fig. 4).

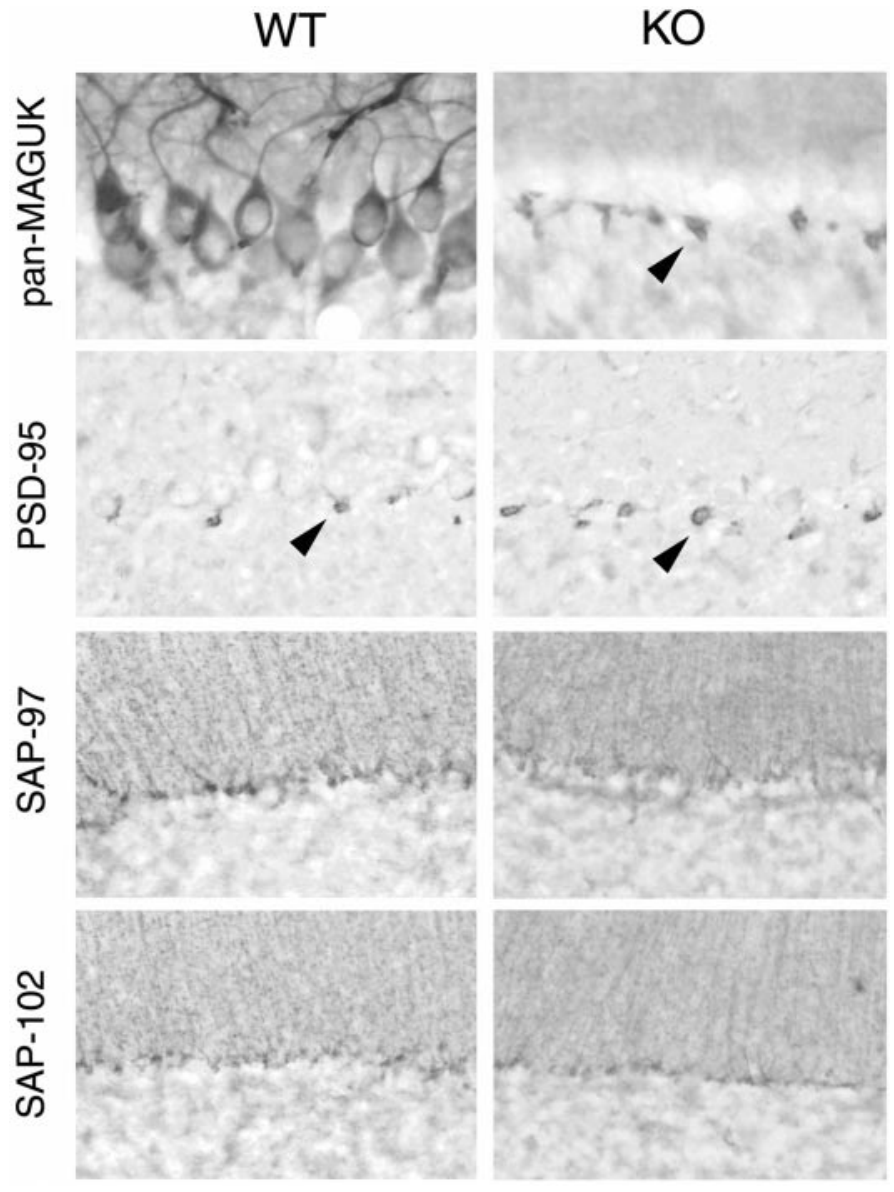

Figure 5. Expression of PSD-93 and related MAGUKs in cerebellum of PSD-93 knock-out mice. Immunohistochemical staining of cerebellum from wild-type $(W T)$ and PSD-93 knock-out $(K O)$ mice using a panantibody that cross-reacts with all four neuronal MAGUKs. In wild-type mouse, strong staining of Purkinje neurons represents PSD-93 (Brenman et al., 1996b; Kim et al., 1996). Staining of the granule cell layer reflects expression of SAP-102 and SAP-97 (Muller et al., 1995, 1996), and labeling of small cone-shaped structures (or pinceaux) beneath the Purkinje cells (arrowheads) represents PSD-95 (Kistner et al., 1993). In the PSD-93 knock-outs, staining is selectively lost from the Purkinje cells. A pan-antibody was used for this Figure to show that no other MAGUK proteins are expressed at detectable levels in Purkinje neurons of the PSD-93 knock-outs. Magnification, 60×.

We also used electron micrographic immunocytochemistry to determine whether the ultrastructural localization of a PSD-93 interacting protein at the synapse is altered in the knock-out mice. Previous work has shown that the $\delta 2$-glutamate receptor associates with PSD-93 in Purkinje cells specifically at the postsynaptic parallel fiber synapse (Roche et al., 1999). Using immunogold, we found that the strong labeling for $\delta 2$ in parallel fiber synapses on Purkinje cells is not different in wild types and knock-outs (Fig. 6); climbing fiber synapses showed little or no labeling for $\delta 2$ in either wild types or knock-outs (data not shown).

\section{Absence of gross motor coordination defects in PSD- 93 knock-out mice}

Careful observation revealed no obvious differences in gait between the wild-type and PSD-93 knock-out mice. As a quantitative measure of motor coordination, we evaluated performance on the rotorod test, which assesses the ability of mice to stay atop 


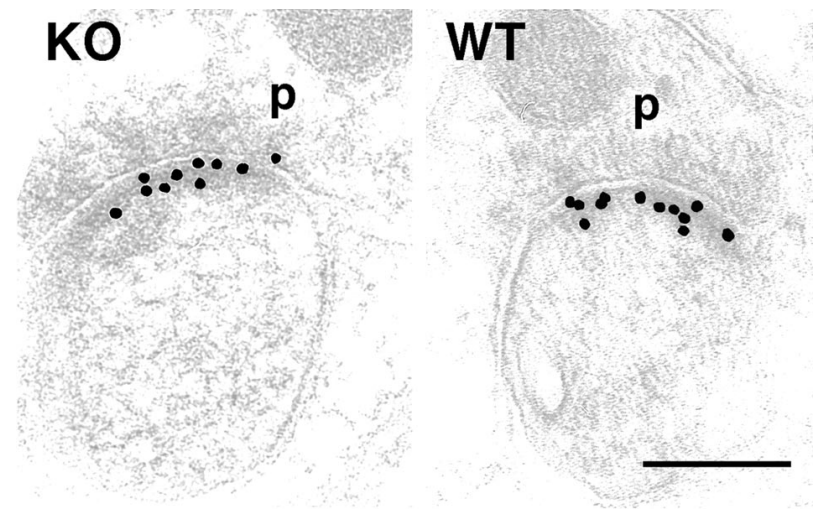

Figure 6. Ultrastructural localization of the $\delta 2$ glutamate receptor in wild-type and mutant cerebellum. Immunogold labeling of parallel fiber/ Purkinje cell spine synapses, with delta $1 / 2$ antibody, in cerebella from PSD-93 knock-out $(K O)$ and wild-type $(W T)$ mice. $p$, presynaptic terminal. Scale bar, $0.2 \mu \mathrm{m}$.

a rotating rod in which angular velocity is constantly increasing. Rodents with abnormalities in cerebellar function often show impairments in this behavioral test (Lalonde et al., 1995; Le Marec et al., 1997). However, we found that PSD-93 mutant mice reached the same level of performance as their wild-type and heterozygote littermates (data not shown).

\section{Normal cerebellar synaptic function in PSD-93 knock-out mice}

Synaptic physiology of the PSD-93 knock-out mice was analyzed in 200-250 $\mu \mathrm{m}$ sagittal slices. We first examined the kinetics of CF- and PF-EPSCs. The $10-90 \%$ rise time and decay time constants were measured in both the wild-type and PSD-93 mutant mice. The decay time constant was obtained by fitting the decay phases of the EPSCs with single exponentials. The kinetics of the rise and decay times for both the CF- and PF-EPSCs were similar in wild-type as compared with PSD-93 knock-out mice (Table 1).

We next examined short-term plasticity of both the CF and PF synapses. Paired-pulse depression of CF-EPSC at interpulse intervals of 10-5000 msec did not differ between wild-type and PSD-93 knock-out mice (Fig. 7A). Similarly, paired pulse facilitation of PF-EPSC at interpulse intervals of 10-300 msec was not altered in PSD-93 mutant mice (Fig. 7B).

During early cerebellar development, Purkinje cells are innervated by multiple climbing fibers, but this is pruned to single climbing fiber innervation by the fourth postnatal week (Crepel, 1982). Mice lacking other synaptic Purkinje cell proteins show abnormal retention of multiple climbing fiber innervation (Kano et al., 1997). However, we found that cerebellar Purkinje neurons from adult PSD-93 knock-out mice show typical single climbing fiber innervation. For these experiments EPSCs were elicited by stimulation of CFs in the granule cell layer of cerebellar slices. As the stimulus intensity was increased gradually, CF-EPSCs in Purkinje cells behaved in an all-or-none fashion and were similar in wild-type and mutant mice (Fig. 8).

\section{DISCUSSION}

This study used targeted mutagenesis of PSD-93 to address the three functional questions that have been raised by previous biochemical studies of MAGUKs. First, do MAGUKs play an essential role in synaptic formation? Second, do MAGUKs play an essential role in the localization of interacting proteins? Third, do MAGUKs play an essential role in the synaptic function of interacting receptors? Our experiments provide support for a negative response to each of these possibilities at parallel fiberPurkinje cell synapses. Because PSD-93 is the only MAGUK protein expressed in cerebellar Purkinje neurons, it seems that functional redundancy cannot explain the normal cerebellar phenotype of the knock-outs.

\section{PSD-93 does not play an essential role in synaptic development}

Our analysis of the PSD-93 knock-out mice failed to show any detectable abnormality of synaptic structure. The dendritic arbors of cerebellar Purkinje neurons and the ultrastructure of postsynaptic climbing fiber and parallel fiber synapses were intact. This is unlike the phenotype of Drosophila discs large (dlg) mutants (Woods and Bryant, 1991), which show blunted development of the subsynaptic reticulum at larval neuromuscular junctions (Lahey et al., 1994).

\section{PSD-93 does not play an essential role in localization of interacting proteins}

Our immunohistochemical studies of the PSD-93 mutant mice failed to detect abnormalities in distribution of PSD-93 interacting proteins. At the light microscopic level, we observed that distribution of GKAP (Kim et al., 1997) was unaltered in cerebellum of the knock-out mice. More importantly, we found a normal synaptic localization of the $\delta$-glutamate receptor at the postsynaptic membrane of Purkinje cell parallel fiber synapses. Although previous studies have shown that $\delta 2$ receptor associates with PSD-93 in cerebellum and that PSD-93 can cluster $\delta 2$ in heterologous cells (Roche et al., 1999), their interaction is clearly not necessary for synaptic localization of $\delta 2$. The normal distribution of $\delta 2$ in cerebellar Purkinje cells contrasts with the altered localization of Shaker type $\mathrm{K}^{+}$channels found in certain $d l g$ mutants of Drosophila (Tejedor et al., 1997).

Table 1. Kinetics of CF-EPSCs and PF-EPSCs

\begin{tabular}{lllcc} 
& & $10-90 \%$ Rise time $(\mathrm{msec})$ & Decay time constant $^{a}(\mathrm{msec})$ & $6.6 \pm 1.1$ \\
\hline CF-EPSC & PSD-93 $(+/+)(n=20)$ & $0.4 \pm 0.1$ & $6.2 \pm 1.4$ \\
& PSD-93 $(-/-)(n=20)$ & $0.4 \pm 0.1$ & $15.9 \pm 7.1$ \\
PF-EPSC & PSD-93 $(+/+)(n=11)$ & $1.3 \pm 0.6$ & $14.6 \pm 3.2$
\end{tabular}

All data are expressed as mean \pm SD.

${ }^{a}$ Decay time constants were obtained by fitting the EPSC decay with a single exponential.

${ }^{b}$ Amplitude of CF-EPSC was measured at the holding potential of $-20 \mathrm{mV}$. 
A

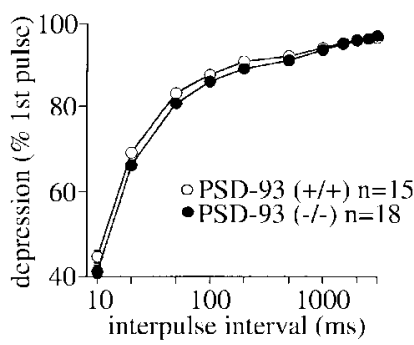

B

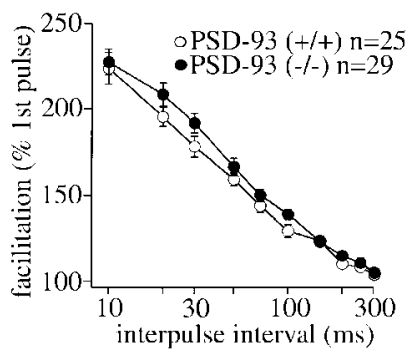

Figure 7. Paired-pulse plasticity of CF- and PF-mediated EPSCs. A, Paired-pulse depression of CF-EPSCs of the wild-type (open circles) and PSD-93 mutant ( filled circles) mice. The amplitude of the second response is expressed as a percentage of the first response (mean \pm SEM) and is plotted as a function of interpulse intervals. Stimulus pairs were applied at $0.1 \mathrm{~Hz}$. B, Paired-pulse facilitation of PF-mediated EPSCs. The amplitude of the second response is expressed as a percentage of the first response (mean $\pm \mathrm{SEM}$ ) and is plotted as a function of interpulse intervals. Stimulus pairs were applied at $0.2 \mathrm{~Hz}$.

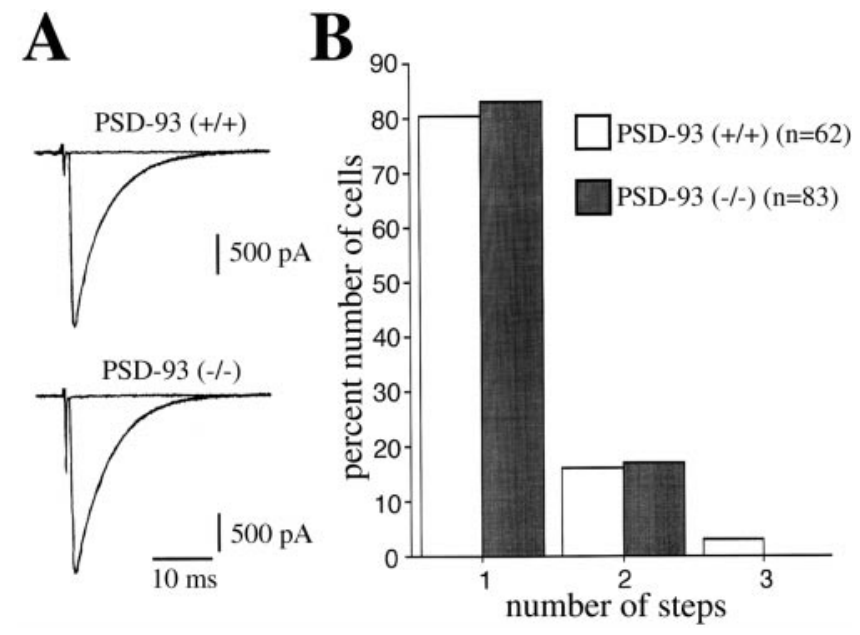

Figure 8. Climbing fiber innervation of Purkinje cells. A, EPSCs elicited by stimulation of climbing fibers (CFs) in the granule cell layer in wild-type (top panel) and PSD-93 mutant (bottom panel) Purkinje cells (PCs). One or three traces were superimposed at each threshold intensity. Stimuli were applied at $0.1 \mathrm{~Hz}$. Holding potentials were $-20 \mathrm{mV}$. B, Summary histograms showing number of discrete steps of CF-EPSCs of the wild-type (open columns; $n=62$ ) and PSD-93 mutant (hatched columns; $n=83$ ) PCs. Data were obtained from three wild-type mice at P57-P70 and four PSD-93 mutant mice at P56-P64. The percentage of PCs with more than two discrete CF-EPSC steps is similar between the two strains ( $p>0.05 ; \chi^{2}$ test for independent samples).

\section{PSD-93 does not play an essential role in synaptic function of interacting receptors}

Mutant mice lacking PSD-95 show abnormal coupling of NMDA receptor to downstream signaling pathways that mediate synaptic plasticity (Migaud et al., 1998). We therefore expected the PSD-93 knock-out to show impaired function of pathways downstream of the $\delta 2$ glutamate receptor, which interacts with PSD-93 and is abundant in Purkinje cells. Although the biochemical activity of $\delta 2$ is unknown, targeted mutation of $\delta 2$ receptor causes persistence of surplus climbing fiber synapses to Purkinje cells and motor discoordination (Kashiwabuchi et al., 1995). However, we found that PSD-93 mutants have normal gait and normal performance on a rotorod test of coordination. Also, PSD-93 mutant mice show monosynaptic climbing fiber innervation of

Purkinje cells. Therefore, PSD-93 does not appear essential for at least some functions of the $\delta 2$ receptor.

\section{Possibilities for redundancy by other PDZ-containing proteins}

Although we found that the PSD-93-related MAGUK proteins PSD-95, SAP-97, and SAP-102, are not expressed in cerebellar Purkinje neurons, it is possible that other proteins containing PDZ domains may compensate for PSD-93. Molecular studies have identified several classes of PDZ domain-containing proteins in neurons. Several proteins containing class one PDZ domains, which bind to the $\mathrm{C}$-terminal Serine-X-Valine motif of NMDA and $\delta 2$ receptors, have been described. For example, S-SCAM and mammalian homologs of lin-7 (MALS/Veli) have been shown to bind NMDA receptors at the PSD (Hirao et al., 1998; Jo et al., 1999) and are likely to bind to $\delta 2$ as well. It remains uncertain whether these proteins or other synaptic PDZ proteins compensate for the loss of PSD-93.

\section{Implications for the function of MAGUKs}

From an evolutionary standpoint, MAGUKs seem vital because they are among the most conserved constituents of the neuronal cytoskeleton (the mouse and human orthologs of both PSD-95 and PSD-93 share $>98 \%$ sequence identity). However, our work suggests that PSD-93 is not essential for development of parallel fiber synapses in cerebellum or for localization and function of at least some interacting proteins. What then might be the essential role for MAGUKs? Rather than determining synaptic structure or protein targeting, MAGUK proteins instead may link postsynaptic receptors to downstream signaling pathways (Craven and Bredt, 1998). This model is consistent with a recent study showing that antisense knockdown of PSD-95 did not influence synaptic localization and function of PSD-95 but blocked NMDA receptors from stimulating nNOS activity (Sattler et al., 1999). We were unable, however, to address this particular pathway in the PSD-93 knock-outs because both NMDA receptors and nNOS are absent from cerebellar Purkinje neurons.

The normal development of PSD-93 and PSD-95 knock-out mice contrasts with the synaptic structural defects in $d l g$ flies (Lahey et al., 1994). However, PSD-93 and PSD-95 are palmitoylated peripheral membrane proteins (Topinka and Bredt, 1998) and are in this way unlike Drosophila DLG. Palmitoylation dramatically alters the sorting and function of PSD-95 and PSD-93 (Craven et al., 1999), which may serve very different neuronal functions than do $d l g$ and its human homolog, SAP-97. It is possible that PSD-93 and PSD-95 do not participate in baseline synaptic signaling but instead have critical functions during extreme physiological situations or in specialized aspects of synaptic plasticity and learning. Indeed, very recent studies show that overexpression of PSD-95 in hippocampal neurons accelerates maturation of excitatory synapses (El-Husseini et al., 2000).

\section{REFERENCES}

Aiba A, Kano M, Chen C, Stanton ME, Fox GD, Herrup K, Zwingman TA, Tonegawa S (1994) Deficient cerebellar long-term depression and impaired motor learning in mGluR1 mutant mice. Cell 79:377-388.

Brenman JE, Chao DS, Gee SH, McGee AW, Craven SE, Santillano DR, Wu Z, Huang F, Xia H, Peters MF, Froehner SC, Bredt DS (1996a) Interaction of nitric oxide synthase with the postsynaptic density protein PSD-95 and $\alpha-1$ syntrophin mediated by PDZ motifs. Cell 84:757-767.

Brenman JE, Christopherson KS, Craven SE, McGee AW, Bredt DS (1996b) Cloning and characterization of postsynaptic density 93, a nitric oxide synthase interacting protein. J Neurosci 16:7407-7415.

Carlin RK, Grab DJ, Siekevitz P (1981) Function of a calmodulin in 
postsynaptic densities. III. Calmodulin-binding proteins of the postsynaptic density. J Cell Biol 89:449-455.

Cho KO, Hunt CA, Kennedy MB (1992) The rat brain postsynaptic density fraction contains a homolog of the Drosophila discs-large tumor suppressor protein. Neuron 9:929-942.

Craven SE, Bredt DS (1998) PDZ proteins organize synaptic signaling pathways. Cell 93:495-498.

Craven SE, Husseini AE, Bredt DS (1999) Synaptic targeting of the postsynaptic density protein PSD-95 mediated by lipid and protein motifs. Neuron 22:497-509.

Crepel F (1982) Regression of functional synapses in the immature mammalian cerebellum. Trends Neurosci 5:266-269.

Edwards FA, Konnerth A, Sakmann B, Takahashi T (1989) A thin slice preparation for patch clamp recordings from neurones of the mammalian central nervous system. Pflügers Arch 414:600-612.

El-Husseini AE, Schnell E, Chetkovitch DM , Nicoll RA, Bredt DS (2000) PSD-95 drives maturation of excitatory synapses. Science 290: $1364-1368$

Firestein BL, Brenman JE, Aoki C, Sanchez-Perez AM, El-Husseini AE, Bredt DS (1999) Cypin-a cytosolic regulator of PSD-95 postsynaptic targeting. Neuron 24:659-672.

Hillier BJ, Christopherson KS, Prehoda KE, Bredt DS, Lim WA (1999) Unexpected modes of PDZ domain scaffolding revealed by structure of nNOS-syntrophin complex. Science 284:812-815.

Hirao K, Hata Y, Ide N, Takeuchi M, Irie M, Yao I, Deguchi M, Toyoda A, Sudhof TC, Takai Y (1998) A novel multiple PDZ domaincontaining molecule interacting with N-methyl-D-aspartate receptors and neuronal cell adhesion proteins. J Biol Chem 273:21105-21110.

Jo K, Derin R, Li M, Bredt DS (1999) Characterization of MALS/ Velis-1, -2, and -3: a family of mammalian LIN-7 homologs enriched at brain synapses in association with the postsynaptic density-95/NMDA receptor postsynaptic complex. J Neurosci 19:4189-4199.

Kano M, Rexhausen U, Dreessen J, Konnerth A (1992) Synaptic excitation produces a long-lasting rebound potentiation of inhibitory synaptic signals in cerebellar Purkinje cells. Nature 356:601-604

Kano M, Hashimoto K, Kurihara H, Watanabe M, Inoue Y, Aiba A, Tonegawa S (1997) Persistent multiple climbing fiber innervation of cerebellar Purkinje cells in mice lacking mGluR1. Neuron 18:71-79.

Kashiwabuchi N, Ikeda K, Araki K, Hirano T, Shibuki K, Takayama C, Inoue Y, Kutsuwada T, Yagi T, Kang Y (1995) Impairment of motor coordination, Purkinje cell synapse formation, and cerebellar long-term depression in GluR delta 2 mutant mice. Cell 81:245-252.

Kennedy MB, Bennett MK, Erondu NE (1983) Biochemical and immunochemical evidence that the "major postsynaptic density protein" is a subunit of a calmodulin-dependent protein kinase. Proc Natl Acad Sci USA 80:7357-7361.

Kim SK (1997) Polarized signaling: basolateral receptor localization in epithelial cells by PDZ-containing proteins. Curr Opin Cell Biol 9:853-859.

Kim E, Niethammer M, Rothschild A, Jan YN, Sheng M (1995) Clustering of Shaker-type $\mathrm{K}+$ channels by direct interaction with the PSD-95/SAP90 family of membrane-associated guanylate kinases. Nature 378:85-88.

Kim E, Cho K-O, Rothschild A, Sheng M (1996) Heteromultimerization and NMDA receptor clustering activity of chapsyn-110, a novel member of the PSD-95 family of synaptic proteins. Neuron 17:103-113.

Kim E, Naisbitt S, Hsueh YP, Rao A, Rothschild A, Craig AM, Sheng M (1997) GKAP, a novel synaptic protein that interacts with the guanylate kinase-like domain of the PSD-95/SAP90 family of channel clustering molecules. J Cell Biol 136:669-678.

Kistner U, Wenzel BM, Veh RW, Cases-Langhoff C, Garner AM, Appeltauer U, Voss B, Gundelfinger ED, Garner CC (1993) SAP90, a rat presynaptic protein related to the product of the Drosophila tumor suppressor gene dlg-A. J Biol Chem 268:4580-4583.

Kornau H-C, Schenker LT, Kennedy MB, Seeburg PH (1995) Domain interaction between NMDA receptor subunits and the postsynaptic density protein PSD-95. Science 269:1737-1740.
Kornau H-C, Seeburg PH, Kennedy MB (1997) Interaction of ion channels and receptors with PDZ domains. Curr Opin Neurobiol 7:368-373.

Lahey T, Gorczyca M, Jia XX, Budnik V (1994) The Drosophila tumor suppressor gene dlg is required for normal synaptic bouton structure. Neuron 13:823-835.

Lalonde R, Bensoula AN, Filali M (1995) Rotorod sensorimotor learning in cerebellar mutant mice. Neurosci Res 22:423-426.

Le Marec N, Caston J, Lalonde R (1997) Impaired motor skills on static and mobile beams in lurcher mutant mice. Exp Brain Res 116:131-138.

Llano I, Marty A, Armstrong CM, Konnerth A (1991) Synaptic- and agonist-induced excitatory currents of Purkinje cells in rat cerebellar slices. J Physiol (Lond) 434:183-213.

Mayat E, Petralia RS, Wang YX, Wenthold RJ (1995) Immunoprecipitation, immunoblotting, and immunocytochemistry studies suggest that glutamate receptor delta subunits form novel postsynaptic receptor complexes. J Neurosci 15:2533-2546.

Migaud M, Charlesworth P, Dempster M, Webster LC, Watabe AM, Makhinson M, He Y, Ramsay MF, Morris RG, Morrison JH, O'Dell TJ, Grant SG (1998) Enhanced long-term potentiation and impaired learning in mice with mutant postsynaptic density-95 protein. Nature 396:433-439.

Muller BM, Kistner U, Veh RW, Cases-Langhoff C, Becker B, Gundelfinger ED, Garner CC (1995) Molecular characterization and spatial distribution of SAP97, a novel presynaptic protein homologous to SAP90 and the Drosophila discs-large tumor suppressor protein. J Neurosci 15:2354-2366.

Muller BM, Kistner U, Kindler S, Chung W K, Kuhlendahl S, Fenster SD, Lau L-F, Veh RW, Huganir RL, Gundelfinger ED, Garner CC (1996) SAP102, a novel postsynaptic protein that interacts with NMDA receptor complexes in vivo. Neuron 17:255-265.

Passafaro M, Sala C, Niethammer M, Sheng M (1999) Microtubule binding by CRIPT and its potential role in the synaptic clustering of PSD-95. Nat Neurosci 2:1063-1069.

Petralia RS, Wenthold RJ (1999) Immunocytochemistry of NMDA receptors. Methods Mol Biol 128:73-92.

Petralia RS, Wang YX, Mayat E, Wenthold RJ (1997) Glutamate receptor subunit 2-selective antibody shows a differential distribution of calcium-impermeable AMPA receptors among populations of neurons. J Comp Neurol 385:456-476.

Petralia RS, Zhao HM, Wang YX, Wenthold RJ (1998) Variations in the tangential distribution of postsynaptic glutamate receptors in Purkinje cell parallel and climbing fiber synapses during development. Neuropharmacology 37:1321-1334.

Roche KW, Ly CD, Petralia RS, Wang YX, McGee AW, Bredt DS, Wenthold RJ (1999) Postsynaptic density-93 interacts with the delta2 glutamate receptor subunit at parallel fiber synapses. J Neurosci 19:3926-3934.

Sattler R, Xiong Z, Lu W-Y, Hafner M, MacDonald JF, Tymianski M (1999) Specific coupling of NMDA receptor activation to nitric oxide neurotoxicity by PSD-95 protein. Science 284:1845-1848.

Sheng M (1996) PDZs and receptor/channel clustering: rounding up the latest suspects. Neuron 17:575-578.

Tejedor FJ, Bokhari A, Rogero O, Gorczyca M, Zhang J, Kim E, Sheng M, Budnik V (1997) Essential role for dlg in synaptic clustering of Shaker K+ channels in vivo. J Neurosci 17:152-159.

Topinka JR, Bredt DS (1998) N-terminal palmitoylation of PSD-95 regulates association with cell membranes and interaction with $\mathrm{K}+$ channel, Kv1.4. Neuron 20:125-134.

Walters BB, Matus AI (1975) Proteins of the synaptic junction. Biochem Soc Trans 3:109-112.

Woods DF, Bryant PJ (1991) The discs-large tumor suppressor gene of Drosophila encodes a guanylate kinase homolog localized at septate junctions. Cell 66:451-464.

Zhao HM, Wenthold RJ, Petralia RS (1998) Glutamate receptor targeting to synaptic populations on Purkinje cells is developmentally regulated. J Neurosci 18:5517-5528. 